\title{
Consequence of Spodoptera litura Fabricius (Lepidoptera: Noctuidae) Morphometrics Reared on Different Cotton Varieties
}

\author{
D.A. Tithi ${ }^{1}$, M.R. Amin ${ }^{1 *}$, S.M.A. Hossain ${ }^{2}$ and H.M.S. Azad ${ }^{2}$ \\ ${ }^{1}$ Department of Entomology, Hajee Mohammad Danesh Science and Technology University, Dinajpur-5200, \\ Bangladesh \\ ${ }^{2}$ Regional Cotton Research Station, Dinajpur-5200, Bangladesh \\ *E-mail: ruhul_hstu@yahoo.com
}

Received: 10.05.2009, Accepted: 27.09.2010

\begin{abstract}
Morphometric characteristics of cotton armyworm Spodoptera litura were studied on cotton varieties CB9, CB10 and SR05. The morphometric parameters of the insect showed that the cotton variety SR05 revealed significantly the highest diameter of egg mass $(7.4 \pm 0.4 \mathrm{~mm})$. The cotton varieties showed significant effect on the length of different larval instars but the breadth of $3^{\text {rd }}$ and $4^{\text {th }}$ instar were statistically different. The studied cotton varieties as food sources did not affect pupal length and also the length and breadth of adults, but pupal breadth showed significant variation. The highest breadth $(6.5 \pm 0.6 \mathrm{~mm})$ of pupa was found when the insects were reared on SR05 variety.
\end{abstract}

Key words: Cotton, morphometrics, Spodoptera litura

\section{Introduction}

There are 162 insect species cause damage to cotton of which a large group of Lepidopteron insects are major pest (AbouElhagag, 1998). Among the Lepidopteron insects, cotton armyworm Spodoptera litura Fabricius (Lepidoptera: Noctuidae) is an economically serious pest of cotton, and reported to attack 120 species of host plants (Chari and Patel, 1983; Zhang, 1994; Pogue, 2003). For proper management of any pest, it is utmost necessary to know its biology and morphological characteristics. Host plant characteristics greatly influence on the feeding, life history and morphometrics of herbivores which have been documented in many cases (McIntyre and Gooding, 2000; Agrawal, 2001). In many insects maternal diet influences egg size, offspring quality and adult size (Rossiter et al., 1993; Jann and Ward, 1999).

Some cotton varieties contain significant levels of tannins that disrupt feeding and growth of chewing insects. The optimal growth of plant feeding insects depends on their ability to acquire essential amino acids from dietary protein (Mattson, 1980; Bernays and Chapman, 1994). Tikkanen et al. (2000) reported that insects are able to grow and develop on a variety of host plant species which characteristic effect on larval growth and survival, pupal development, adult emergence, adult size and weight. Cotton plants contain trichomes which are epidermal appendages such as non glandular hairs, scales, or pelts hairs. Trichomes affect the insect behavior by 
providing a barrier that prevents landing on the plant surface and prevent movement and feeding (Goertzen and Small, 1993). For example, trichome effect on the feeding behavior of Colorado potato beetle, Leptinotarsa decemlineata (Yencho and Tingey, 1994). Therefore, the aim of this study is to know the effect of three cotton varieties as food type on the development of $S$. litura in an attempt to determine which of the cotton variety is the most favorable diet for developing this species and the efficiency of the diet was assessed by evaluating the diameter of egg mass, larval, pupal and adult size.

\section{Materials and methods}

This study was conducted in the Entomology Laboratory, Hajee Mohammad Danesh Science and Technology University, Dinajpur, Bangladesh from September 2008 to February 2009. Adult male and female moths of S. litura were collected from the cotton field and they were reared in the laboratory at $25 \pm 2^{\circ} \mathrm{C}, 60 \pm 5 \%$ humidity and 12:12 light: dark condition providing with fresh cotton flower of CB9, CB10 and SR05 variety as diet. The cotton varieties were cultivated without insecticide treatment. The moths were kept in different petridishes $(9.0 \times 1.5 \mathrm{~cm})$ for mating. After completion of mating, the male moths were removed from the petridishs and the females were kept in jars $(26.5 \times 13.5 \mathrm{~cm})$ for oviposition. Cotton leaves and flowers were supplied into the jars. Every morning the petridishes were cleaned and monitored to observe the egg mass. After hatching, fresh cotton leaves were supplied into the jars for food of the young larvae till pupation. Newly emerged adult male and females were further reared for this study. The morphometric parameters viz. the length and breadth of larvae, pupae and adults were measured with the help of ordinary millimeter scale and the diameter of egg mass were taken by using steriomicroscope. Data were analyzed by analysis of variance and the mean values were separated by Duncan's Multiple Range Test (DMRT).

\section{Results and discussion}

Cotton armyworms laid eggs in masses on the under side of the cotton leaves or on the petridishes. The observed diameter of the egg masses were significantly different and which measured $4.4 \pm 0.4, \quad 5.6 \pm 0.4$ and $7.4 \pm 0.4 \mathrm{~mm}$ when the insects were reared on CB9, CB10 and SR05 variety, respectively (Tab. 1). Table 1 showed that larval length varied with sources of food. The length of $1^{\text {st }}, 2^{\text {nd }}, 3^{\text {rd }}, 4^{\text {th }}$ and $5^{\text {th }}$ instar larvae varied from $8.9 \pm 0.9$ to $10.2 \pm 0.8$, $13.5 \pm 1.0$ to $16.3 \pm 1.5,20.5 \pm 1.9$ to $24.5 \pm 0.6$, $28.8 \pm 1.5$ to $32.3 \pm 2.8$ and $47.5 \pm 1.9$ to $50.5 \pm 1.9 \mathrm{~mm}$, respectively. The breadth of $1^{\text {st }}, 2^{\text {nd }}, 3^{\text {rd }}, 4^{\text {th }}$ and $5^{\text {th }}$ instar larvae were measured $1.3 \pm 0.2$ to $1.5 \pm 0.2,2.3 \pm 0.5$ to $2.5 \pm 0.5,3.3 \pm 0.5$ to $4.0 \pm 0.8,4.8 \pm 0.5$ to $6.0 \pm 0.8$ and $7.8 \pm 0.5$ to $8.3 \pm 0.4 \mathrm{~mm}$, respectively (Tab. 1). First, second and fifth instar larvae did not show significant variation in their breadth but the $3^{\text {rd }}$ and $4^{\text {th }}$ instar larval breadth showed significant variation. The $3^{\text {rd }}$ instar larvae showed highest $(4.0 \pm 0.8 \mathrm{~mm})$ and lowest $(3.3 \pm 0.5$ $\mathrm{mm}$ ) breadth when they were reared on CB9 and $\mathrm{CB} 10$ variety, respectively, whereas the $4^{\text {th }}$ instar larvae attained highest $(6.0 \pm 0.8$ $\mathrm{mm})$ and lowest $(4.8 \pm 0.5 \mathrm{~mm})$ breadth when they fed SR05 and CB10 variety, respectively.

Table 1 showed that the studied cotton varieties as food sources did not affect the length of $S$. litura pupae, adult males and females. However, the length of 
D.A. Tithi, M.R. Amin, S.M.A. Hossain and H.M.S. Azad / Our Nature (2010) 8: 118-121

Table 1. Morphometric parameters of S. litura feeding on different cotton varieties

\begin{tabular}{|c|c|c|c|}
\hline \multirow{2}{*}{ Morphometric parameters } & \multicolumn{3}{|c|}{ Cotton variety } \\
\hline & CB9 & CB10 & SR05 \\
\hline Diameter of egg mass $(\mathrm{mm})$ & $4.4 \pm 0.4$ & $5.6 \pm 0.4$ & $7.4 \pm 0.4$ \\
\hline \multicolumn{4}{|l|}{ Length of larval instar (mm) } \\
\hline $1^{\text {st }}$ instar & $10.2 \pm 0.8 \mathrm{a}$ & $8.9 \pm 0.9 \mathrm{ab}$ & $9.1 \pm 0.8 \mathrm{ab}$ \\
\hline $2^{\text {nd }}$ instar & $16.3 \pm 1.5 \mathrm{a}$ & $14.8 \pm 0.5 \mathrm{ab}$ & $13.5 \pm 1.0 \mathrm{~b}$ \\
\hline $3^{\text {rd }}$ instar & $24.5 \pm 0.6 \mathrm{a}$ & $20.5 \pm 1.9 b$ & $21.5 \pm 1.0 \mathrm{~b}$ \\
\hline $4^{\text {th }}$ instar & $28.8 \pm 1.5 b$ & $29.5 \pm 1.0 \mathrm{~b}$ & $32.3 \pm 2.8 \mathrm{a}$ \\
\hline $5^{\text {th }}$ instar & $47.5 \pm 1.9 \mathrm{~b}$ & $49.5 \pm 2.5 \mathrm{a}$ & $50.5 \pm 1.9 \mathrm{a}$ \\
\hline \multicolumn{4}{|l|}{ Breadth of larval instar (mm) } \\
\hline $1^{\text {st }}$ instar & $1.3 \pm 0.2 \mathrm{a}$ & $1.3 \pm 0.3 \mathrm{a}$ & $1.5 \pm 0.2 \mathrm{a}$ \\
\hline $2^{\text {nd }}$ instar & $2.3 \pm 0.5 \mathrm{a}$ & $2.3 \pm 0.5 \mathrm{a}$ & $2.5 \pm 0.5 \mathrm{a}$ \\
\hline $3^{\text {rd }}$ instar & $4.0 \pm 0.8 \mathrm{a}$ & $3.3 \pm 0.5 \mathrm{ab}$ & $3.8 \pm 0.5 \mathrm{a}$ \\
\hline $4^{\text {th }}$ instar & $5.3 \pm 0.5 \mathrm{ab}$ & $4.8 \pm 0.5 \mathrm{ab}$ & $6.0 \pm 0.8 \mathrm{a}$ \\
\hline $5^{\text {th }}$ instar & $7.8 \pm 0.5 \mathrm{a}$ & $7.8 \pm 0.5 a$ & $8.3 \pm 0.4 \mathrm{a}$ \\
\hline Length of pupae (mm) & $20.0 \pm 0.8 \mathrm{a}$ & $19.8 \pm 0.9 \mathrm{a}$ & $19.0 \pm 0.8 \mathrm{a}$ \\
\hline Breadth of pupae (mm) & $5.9 \pm 0.3 \mathrm{ab}$ & $5.9 \pm 0.9 \mathrm{ab}$ & $6.5 \pm 0.6 \mathrm{a}$ \\
\hline Length of adult $\hat{\sigma}(\mathrm{mm})$ & $16.9 \pm 0.3 a$ & $17.3 \pm 0.5 \mathrm{a}$ & $17.1 \pm 0.6 \mathrm{a}$ \\
\hline Length of adult $Q$ (mm) & $20.2 \pm 0.5 \mathrm{a}$ & $20.5 \pm 0.4 \mathrm{a}$ & $20.3 \pm 0.6 a$ \\
\hline Breadth of adult $\hat{\delta}(\mathrm{mm})$ & $5.3 \pm 0.5 \mathrm{a}$ & $5.8 \pm 0.3 a$ & $5.2 \pm 0.3 \mathrm{a}$ \\
\hline Breadth of adult $+(\mathrm{mm})$ & $7.8 \pm 0.5 \mathrm{a}$ & $7.7 \pm 0.8 \mathrm{a}$ & $8.0 \pm 0.3 \mathrm{a}$ \\
\hline
\end{tabular}

Means within a row followed by no common letter(s) are significantly different (DMRT, $\mathrm{p} \leq 0.05$ ). $\mathrm{N}=5$ for each variety and parameter.

pupae, adult males and females were varied from $19.0 \pm 0.8$ to $20.0 \pm 0.8,16.9 \pm 0.3$ to $17.3 \pm 0.5$ and $20.2 \pm 0.5$ to $20.5 \pm 0.4 \mathrm{~mm}$, respectively. On the contrary, the studied cotton varieties showed significant effect on the breadth of pupae but the breadth of adult males and females were statistically similar. The pupae, adult males and female's breadth ranged from $5.9 \pm 0.3$ to $6.5 \pm 0.6$, $5.2 \pm 0.3$ to $5.8 \pm 0.3$ and $7.7 \pm 0.8$ to $8.0 \pm 0.3$ $\mathrm{mm}$, respectively. The pupae attained highest breadth $(6.5 \pm 0.6)$ when the insects were reared on SR05 variety (Tab. 1).

Ou-Yang and Chu (1994) reared $S$. litura on an artificial diet and observed the average body length of male $20.9 \pm 1.1 \mathrm{~mm}$ and female $20.2 \pm 1.0 \mathrm{~mm}$ on the day of emergence. In this study, the length of males and females were measured $16.9 \pm 0.3$ to $17.3 \pm 0.5$ and $20.2 \pm 0.5$ to $20.5 \pm 0.4 \mathrm{~mm}$, respectively. Plants have many external structural defenses that discourage insects feeding. Plant morphology has been shown to influence the biology of herbivores through feeding preferences (Legrand and Barbosa, 2000). The early instar stages of insects are particularly sensitive to overall physiological and biochemical functions (Scriber, 1981). The studied cotton varieties are morphologically different which may influence on the amount of food consumption, production of excreta and duration of different life stages of $S$. litura as a result some morphometrics of the insects showed variation.

\section{References}

Abou-Elhagag, G.H. 1998. Seasonal abundance of certain cotton pest and their associated natural enemies in Southern Egypt. Assiat. J. Agril. Sci. 29: 253-267. 
D.A. Tithi, M.R. Amin, S.M.A. Hossain and H.M.S. Azad / Our Nature (2010) 8: 118-121

Agrawal, A.A. 2001. Transgenerational consequences of plant responses to herbivory: an adaptive maternal effect? Am. Nat. 157: 555-569.

Bernays, E.A. and R.F. Chapman 1994. Host-plant selection by phytophagous insects. Chapman and Hall, New York. 238 p.

Chari, M.S. and N.G. Patel 1983. Cotton leaf worm Spodoptera litura (Fabr.): its biology and integrated control measures. Cotton Develop. 13: $7-8$.

Goertzen, L.R. and E. Small 1993. The defensive role of trichomes in black meduck Medicago lupulina F. Plant Syst. Evol. 184: 101-111.

Jann, P. and P.I. Ward 1999. Maternal effects and their consequences for offspring fitness in the yellow dung fly. Funct. Ecol. 13: 51-58.

Legrand, A. and P. Barbosa 2000. Pea aphid (Homoptera: Aphididae) fecundity, rate of insrease, and within-plant distribution unaffected by plant morphology. Environ. Entomol. 29: 987-993.

Mattson, W.J.J. 1980. Herbivory in relation to plant nitrogen content. Ann. Rev. Ecol. Syst. 11: 119-161.

McIntyre, G.S. and R.H. Gooding 2000. Effects of maternal age on larval competitiveness in house flies. Heredity 85: 480-489.

Ou-Yang, S. and Y. Chu 1994. The body weight, carbohydrate and lipid content of various aged adults of the tobacco cutworm. Chinese $J$. Entomol. 14: 173-182.

Pogue, M.G. 2003. World Spodoptera database (Lepidoptera: Noctuidae). US Department of Agriculture, Systematics and Entomology Laboratory, Beltsville, MD.

Rossiter, M.C., D.L. Coxfoster and M.A. Briggs 1993. Initiation of maternal effects in Lymantria dispar genetic and ecological components of egg provisioning. J. Evol. Biol. 6: 577-589.

Scriber, J.M. 1981. Sequential diets, metabolic costs, and growth of Spodoptera eridamia (Lepidoptera: Noctuidae) feeding upon dill, lima bean, and cabbage. Oecologia 51: 175180.

Tikkanen, O.P., P. Niemela, J. Keranen 2000. Growth and development of a generalist insect herbivore, Operophtera brumata on original and alternative host plants. Oecologia 122: 529-536.

Yencho, G.C. and W.M. Tingey 1994. Glandular trichomes of Solanum berthaultii alter hot preference of Colorado potato beetle, Leptinotarsa decemlineata. Ent. Exp. Appl. 70: $217-225$.

Zhang, B.C. 1994. Index of economically important Lepidoptera. CAB International, Wallingford, UK. 